\title{
PREPARATION OF ANTIMICROBIAL PAPER BY MICROWAVE-ASSISTED TWO-POT IN-SITU DEPOSITION OF ZINC OXIDE ON FILTER PAPER
}

\author{
GENNE PATT O. SAMAR, ${ }^{*}$ ALVIN KARLO G. TAPIA, ${ }^{*}$ \\ CHRYSLINE MARGUS N. PIÑOL, NACITA B. LANTICAN, ${ }^{* *}$ MA. LOURDES F. DEL MUNDO, ${ }^{* *}$ \\ RONNIEL D. MANALO*** and MARVIN U. HERRERA* \\ "Institute of Mathematical Sciences and Physics, University of the Philippines Los Baños, College, Laguna \\ 4031, Philippines \\ **Institute of Biological Sciences, University of the Philippines Los Baños, \\ College, Laguna 4031, Philippines \\ *** Department of Forest Products and Paper Science, University of the Philippines Los Baños, College, \\ Laguna 4031, Philippines \\ $₫$ Corresponding author: M. U. Herrera, muherrera@up.edu.ph
}

Received June 20, 2020

We employed a microwave-assisted two-pot in-situ deposition technique to incorporate zinc oxide particulates in the structure of filter paper to produce antimicrobial paper. The process involved successive immersion of filter paper samples in $\mathrm{ZnSO}_{4}$ (precursor solution) and $\mathrm{NaOH}$ (precipitating agent) to form $\mathrm{Zn}(\mathrm{OH})_{2}$, which transformed into $\mathrm{ZnO}$ during microwave treatment. Successful deposition of $\mathrm{ZnO}$ particles on the filter paper was confirmed via X-ray diffraction and the corresponding morphologies were observed using field emission scanning electron microscopy. The $\mathrm{ZnO}$-deposited papers were tested for antimicrobial activity and were found to be more effective against Staphylococcus aureus (gram-positive) than Escherichia coli (gram-negative). Bacterial populations were reduced by up to $92 \pm 2 \%$ and $57 \pm 4 \%$ for $S$. aureus and E. coli, respectively. Also, it was found that the samples prepared using higher concentrations of $\mathrm{ZnSO}_{4}$ and $\mathrm{NaOH}$ exhibited better antimicrobial properties.

Keywords: filter paper, in-situ $\mathrm{ZnO}$ deposition, two-pot process, microwave treatment, antimicrobial activity

\section{INTRODUCTION}

An approach to minimizing the spread of communicable diseases is through incorporation of antimicrobial agents on different surfaces. The process of incorporating antimicrobial agents might be challenging for some surfaces, especially if the surfaces are inert and smooth. Alternatively, difficult-to-functionalize surfaces can be covered with antimicrobial paper. Having the inherent flexibility of paper, antimicrobial paper can be easily tailored to fit a wide variety of surfaces; it can be cut into different shapes and sizes, as well as folded and bended. Paper is a material composed mainly of cellulose, which is sensitive to bacterial decomposition. The incorporation of antimicrobial agents into the internal structure of paper not only gives rise to antimicrobial properties, it can also lengthen the decomposition time of paper.
A wide variety of organic and inorganic materials have been used to produce antimicrobial paper. Organic antimicrobial agents include alcohol (isopropyl alcohol) and those that have been derived from animals and plants (such as oil,$~^{1-2}$ chitosan $^{3-4}$ and its derivatives ${ }^{5}$ ). Tissue papers with alcohol are already available on the market. They have been deemed effective in killing a wide range of microorganisms. However, alcohol is volatile and thus easily evaporates. These wet tissue papers need always to be kept in a sealed container for the organic solvent to remain on the paper. Animal and plant derived antimicrobial agents are used when the paper is intended to come in direct contact with our mouth or with food, such as food wrappings. Oils extracted from animals and plants also evaporate, thus reducing the lifetime of the antimicrobial 
paper. Inorganic antimicrobial agents include metal and metal oxides. ${ }^{6-8}$ Inorganic antimicrobial agents are more stable, compared to their organic counterparts, and thus can produce papers with longer antimicrobial lifetime. Silver is a known inorganic antimicrobial agent. Silver-incorporated papers are used as packaging for eating utensils. However, the raw materials needed to incorporate silver into paper are expensive. The raw materials for zinc oxide are a cheaper alternative. Zinc oxide is generally recognized as safe by the U.S. Food and Drug Administration (21CFR182.8991). It has been used in different health and wellness products.

$\mathrm{ZnO}$-incorporated papers have been a topic of much research interest in recent years. ${ }^{9-18} \mathrm{ZnO}$ particles can be incorporated into the bulk of the paper product during the manufacturing process or embedded locally on the surface of prefabricated paper, where they can interact directly with the environment. The latter can be done either by direct assembly of synthesized $\mathrm{ZnO}$ particles or by in-situ assembly. In in-situ assembly methods, particles are synthesized as they are embedded into the paper. The synthesis and embedding of particles can be done by immersing the substrate into a pot containing the needed precursors. Using only one vessel, however, can be disadvantageous, as the desired particles may form not only on the substrate, but in the entire solution. This problem can be avoided by using two vessels. The first vessel contains a precursor, while the second vessel contains a solution that facilitates the required chemical reaction. In this two-pot method, the precursors trapped in the pores of the paper substrate serve as seed for growth and synthesis of the desired particles on and near the surface of the substrate.

The in-situ assembly methods described above require intensive heat treatment. However, prolonged exposure to intense heat can potentially damage the paper substrates. Hence, the necessary chemical reactions must be carried out within a short span of time, in no more than a few minutes, such as in a microwave oven. Microwaves have the ability to transfer energy directly to the reactive components. This is not possible in the conventional heating methods.

In this study, we prepared antimicrobial active paper by in-situ generation and incorporation of $\mathrm{ZnO}$ particles on filter paper. In particular, we used a microwave-assisted two-pot in-situ deposition technique. The antimicrobial activity of the ZnO-deposited papers was tested against Staphylococcus aureus and Escherichia coli. The former represents gram-positive bacteria, while the latter - gram-negative bacteria. The effect of different preparation parameters (precursor concentration, precipitating agent concentration and microwave exposure time) on the antimicrobial properties of the functionalized papers was also examined.

\section{EXPERIMENTAL}

\section{Materials}

The substrates used were Whatman No. 1 filter papers. The precursor and precipitating agent used were zinc sulfate heptahydrate salts (AR, HiMedia Laboratories Pvt. Ltd.) and sodium hydroxide powder (AR, Macron Fine Chemicals), respectively.

\section{Microwave-assisted two-pot in-situ deposition of zinc oxide on filter paper}

Filter papers were dipped successively in the $\mathrm{ZnSO}_{4}$ and $\mathrm{NaOH}$ solutions at different soaking times. Afterwards, the samples were subjected to microwave irradiation. During the treatment, the papers were immersed in water to avoid being burned. The microwave oven (General Electric model JEI2340WPSL) used had a pre-set power of $540 \mathrm{~W}$.

\section{Characterization}

Successful deposition of $\mathrm{ZnO}$ particles on the filter papers was confirmed using X-ray diffraction (Shimadzu XRD-6100). The morphology of the samples was observed using a Field Emission Scanning Electron Microscope (FEI Helios Nanolab $600 \mathrm{i}$ FESEM). Mass differences of the samples prepared using different $\mathrm{ZnSO}_{4}$ and $\mathrm{NaOH}$ concentrations, as well as soaking times, were noted.

\section{Antimicrobial test}

The antimicrobial properties of the samples were determined using the standard test method for determining the antimicrobial activity of immobilized antimicrobial agents under dynamic contact conditions (ASTM E2149-01). The test organisms used were Staphylococcus aureus (BIOTECH 1582) and Escherichia coli (BIOTECH 1634). In this method, the test culture was incubated in nutrient broth (Difco: 8 $\mathrm{g} / \mathrm{L})$, which in turn was diluted in a sterilized $0.3 \mathrm{mM}$ phosphate buffer. To obtain the working bacterial dilution of $1.5-3.0 \times 10^{5}$ colony forming units $(\mathrm{CFU}) / \mathrm{mL}$, subsequent dilution was made. The Mcfarland standard was used in the preparation of the test organisms.

The paper samples that were analyzed were $\sim 0.2 \mathrm{~g}$. The paper samples were placed in a $50 \mathrm{~mL}$ working bacterial dilution, and then incubated for 1 hour at 37 ${ }^{\circ} \mathrm{C}$ (with shaking at $120 \mathrm{rpm}$ ). Using a buffer solution, serial dilution was again done. After which, $1 \mathrm{~mL}$ was 
plated onto Nutrient Agar. The plated agar was incubated at $37{ }^{\circ} \mathrm{C}$ for 24 hours. The antimicrobial property of the sample was expressed as the percent reduction of the test organism after one hour of contact with the paper sample, as compared to the number of organism cells after contact with the control.

\section{RESULTS AND DISCUSSION}

The microwave-assisted two-pot technique involved successive soaking of the filter papers into the precursor $\left(\mathrm{ZnSO}_{4}\right)$ and precipitating agent $(\mathrm{NaOH})$ solutions. The precursor solution in the first pot contained zinc ions:

$\mathrm{ZnSO}_{4}$ (aqueous solution) $\rightarrow \mathrm{Zn}^{+2}+\mathrm{SO}_{4}{ }^{-2}$

These ions are small enough to penetrate the pores of the paper. As the filter papers are soaked in the precursor, a considerable amount of $\mathrm{ZnSO}_{4}$ adheres to the substrates. On the other hand, the precipitating agent in the second pot contained $\mathrm{OH}$ ions:

$\mathrm{NaOH}$ (aqueous solution) $\rightarrow \mathrm{Na}^{+1}+\mathrm{OH}^{-1}$

When dipped in the second solution, $\mathrm{Zn}$ ions on the substrate react with the $\mathrm{OH}$ ions to form zinc hydroxide:

$\mathrm{Zn}^{+2}+\mathrm{OH}^{-1} \rightarrow \mathrm{Zn}(\mathrm{OH})_{2}$

Figure 1a shows the XRD pattern of a filter paper that has been immersed in the two solutions without undergoing microwave treatment. The peaks at $14.5,16.1$ and $22.5^{\circ}$ (labeled ' $\mathrm{x}$ ') correspond to the $(1 \overline{10}),(110)$ and (200) planes of cellulose, respectively. The peaks at 25.8 and $33.6^{\circ}$ correspond to (011) and (211) planes of $\varepsilon$ $\mathrm{Zn}(\mathrm{OH})_{2}$, while the peak at about $30.2^{\circ}$ may be attributed to metastable $\beta-\mathrm{Zn}(\mathrm{OH})_{2}$. These peaks associated to the presence of $\mathrm{Zn}(\mathrm{OH})_{2}$ are labeled ' $\mathrm{y}$ '.

During the microwave treatment, the filter papers were kept in a water bath to prevent them from burning. Two possible reactions may have occurred in the process:

$\mathrm{Zn}(\mathrm{OH})_{2} \rightarrow \mathrm{ZnO}+\mathrm{H}_{2} \mathrm{O}$
$\mathrm{Zn}(\mathrm{OH})_{2}+\mathrm{O}_{2} \rightarrow \mathrm{ZnO}+\mathrm{H}_{2} \mathrm{O}+\mathrm{O}_{2}$

In both cases, $\mathrm{Zn}(\mathrm{OH})_{2}$ changed into $\mathrm{ZnO}$. The XRD pattern of a sample subjected to microwave treatment for 8 minutes is shown in Figure 1b. We observe the same peaks corresponding to cellulose. We also find new peaks (labeled ' $z$ ') corresponding to the (100), (002) and (101) planes of zinc oxide. These peaks located at 31.7, 34.5 and $36.1^{\circ}$ confirm successful deposition of $\mathrm{ZnO}$ on the substrates.

\section{Soaking times}

First, we examined the effect of varying $\mathrm{ZnSO}_{4}$ soaking times on the functionalized papers by noting changes in the mass of the filter papers before and after deposition (Fig. 2). In sample preparation, $350 \mathrm{mM} \mathrm{ZnSO}_{4}$ and $700 \mathrm{mM} \mathrm{NaOH}$ solutions were used. The substrates were immersed in $\mathrm{ZnSO}_{4}$ at pre-determined times, soaked in $\mathrm{NaOH}$ for one minute, and subjected to microwave treatment for 10 minutes.

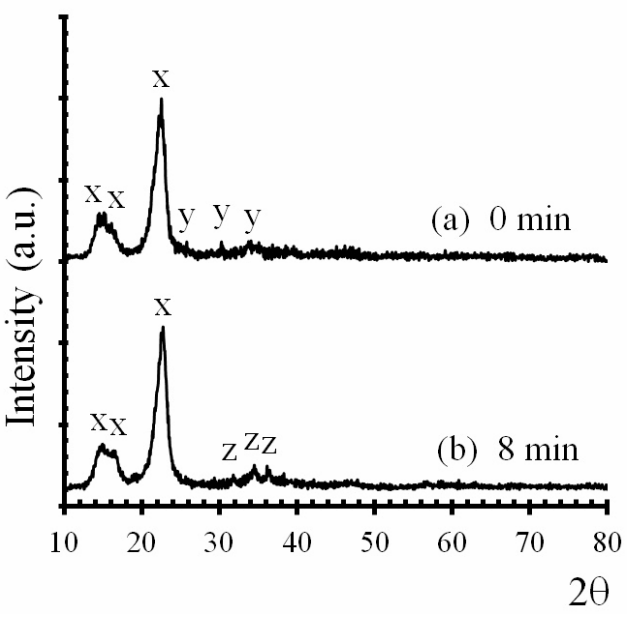

Figure 1: X-ray diffraction pattern of samples prepared with (a) 0 min and (b) 8 min microwave treatment. Peaks labeled ' $\mathrm{x}$ ', ' $\mathrm{y}$ ', and ' $\mathrm{z}$ ' are indicative of cellulose, $\mathrm{Zn}(\mathrm{OH})_{2}$, and $\mathrm{ZnO}$, respectively (preparation conditions: $350 \mathrm{mM}$ $\mathrm{ZnSO}_{4}, 700 \mathrm{mM} \mathrm{NaOH}, 1$ min soaking time, and eight min microwave exposure time) 


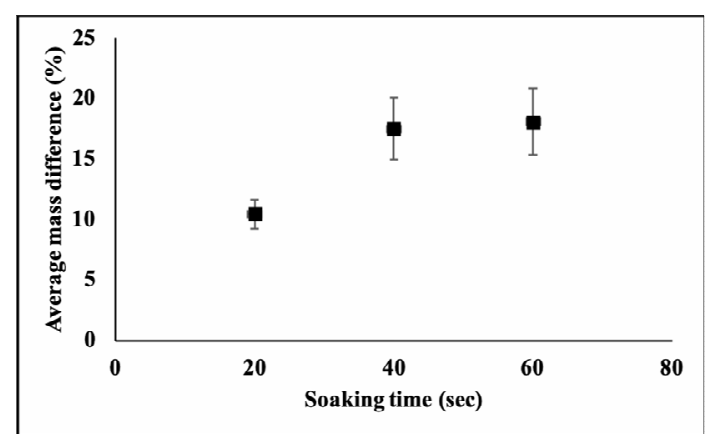

Figure 2: Average mass differences of functionalized papers prepared using different $\mathrm{ZnSO}_{4}$ soaking times under the following conditions: $350 \mathrm{mM} \mathrm{ZnSO}$, 700 $\mathrm{mM} \mathrm{NaOH}, 1 \mathrm{~min} \mathrm{NaOH}$ soaking time, and $10 \mathrm{~min}$ microwave exposure time

On the average, the mass of the filter papers dipped in the precursor solution for 20 seconds increased by $10 \%$. When the $\mathrm{ZnSO}_{4}$ soaking time was doubled, the samples registered a mass difference of about $15-20 \%$. A larger positive mass difference could mean that more $\mathrm{ZnO}$ particles have been embedded on the filter papers. However, prolonged immersion in the precursor solution does not necessarily imply greater deposition of $\mathrm{ZnO}$ particles. There is no significant difference in the observed mass gain of the substrates soaked in $\mathrm{ZnSO}_{4}$ for 40 and 60 seconds.

Next, we modified the length of time the samples were immersed in the precipitating agent solution, while fixing the $\mathrm{ZnSO}_{4}$ soaking time to one minute (or 60 seconds). Likewise, $350 \mathrm{mM}$ $\mathrm{ZnSO}_{4}$ and $700 \mathrm{mM} \mathrm{NaOH}$ solutions were used in the preparation samples and microwave exposure time was set to 10 minutes. Data showed no significant change in the amount of mass gained by the substrates with increasing $\mathrm{NaOH}$ soaking time (Fig. 3). After immersion in the precursor solution, the substrates could have been close to saturation and could no longer absorb more $\mathrm{NaOH}$, even if soaking times were extended.

\section{$\mathrm{ZnSO}_{4}$ concentration}

We varied the concentration of the precursor solution, while keeping all the other preparation parameters constant. Results showed that increasing the $\mathrm{ZnSO}_{4}$ concentration has no direct effect on the amount of additional mass acquired by the substrates during the embedding process (Fig. 4). The solubility of $\mathrm{ZnSO}_{4}$ may have been too high (at $100 \mathrm{mg} / 1 \mathrm{~mL}$ or $\sim 348 \mathrm{mM}$ zinc

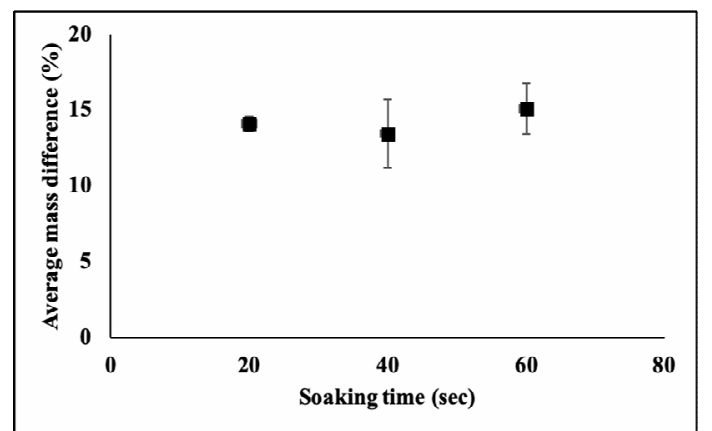

Figure 3: Average mass differences of functionalized papers prepared using different $\mathrm{NaOH}$ soaking times under the following conditions: $350 \mathrm{mM} \mathrm{ZnSO}$, 700 $\mathrm{mM} \mathrm{NaOH}, 1 \mathrm{~min} \mathrm{ZnSO}_{4}$ soaking time, and $10 \mathrm{~min}$ microwave exposure time

sulfate solution) to allow distinct detectable difference in the amount of deposited mass. However, in terms of antimicrobial activity against $S$. aureus and $E$. coli, the samples prepared using higher concentrations of $\mathrm{ZnSO}_{4}$ were more effective in reducing bacterial populations (Table 1). After one hour of contact, $S$. aureus and E. coli populations decreased by up to $92 \pm 2 \%$ and $57 \pm 4 \%$, respectively. The antimicrobial properties observed for the samples prepared without $\mathrm{ZnSO}_{4}$ may be attributed entirely to sodium hydroxide, which is a known disinfectant.

\section{$\mathrm{NaOH}$ concentration}

In a similar way, we prepared samples using different $\mathrm{NaOH}$ concentrations. The mass gain of the functionalized papers, due to embedded particles, was greater at higher $\mathrm{NaOH}$ concentrations (Fig. 5). This may be attributed to the presence of more hydroxyl ions (OH-), which triggered the formation of $\mathrm{Zn}(\mathrm{OH})_{2}$, which is necessary to produce $\mathrm{ZnO}$.

The effects of varying $\mathrm{NaOH}$ concentrations on the antimicrobial activity of the samples are summarized in Table 2 . The samples that were not soaked in $\mathrm{NaOH}$ solution, but were immersed in $\mathrm{ZnSO}_{4}$ solution and subjected to microwave treatment, were able to reduce the population of $S$. aureus and E. coli by $32 \pm 6 \%$ and $17 \pm 2 \%$, respectively, after one hour of contact. This may be due to residual $\mathrm{Zn}$-based materials that have accumulated on the substrates during the treatment. Data also indicate better antimicrobial activity in samples produced using higher concentrations of $\mathrm{NaOH}$. The papers 
functionalized using $700 \mathrm{mM} \mathrm{NaOH}$ precipitating agent were able to reduce $S$. aureus and $E$. coli

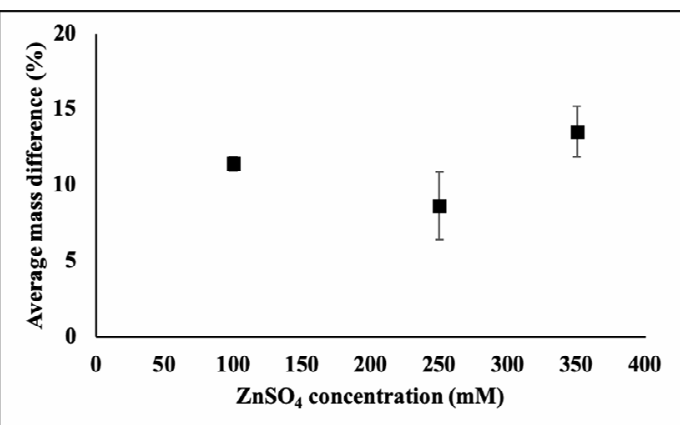

Figure 4: Average mass differences of functionalized papers prepared using different concentrations of $\mathrm{ZnSO}_{4}$ under the following conditions: $700 \mathrm{mM}$ $\mathrm{NaOH}, 1$ min soaking time, and $10 \mathrm{~min}$ microwave exposure time populations by $89 \pm 2 \%$ and $43 \pm 3 \%$, respectively.

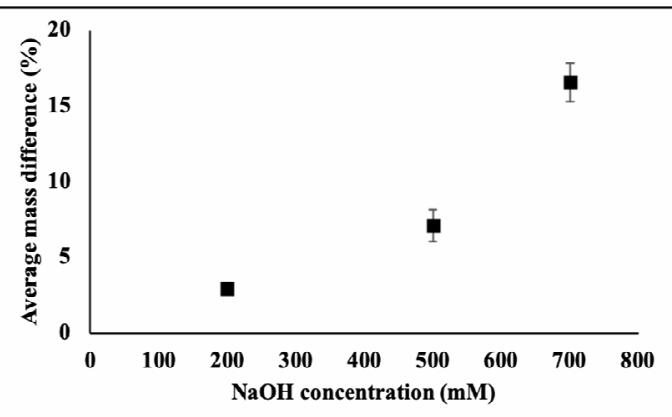

Figure 5: Average mass differences of functionalized papers prepared using different concentrations of $\mathrm{NaOH}$ under the following preparation conditions: 350 $\mathrm{mM} \mathrm{ZnSO}_{4}, 1 \mathrm{~min}$ soaking time, and $10 \mathrm{~min}$ microwave exposure time

Table 1

Antimicrobial activity of samples prepared using different concentrations of $\mathrm{ZnSO}_{4}$ under the following conditions: 700 $\mathrm{mM} \mathrm{NaOH}, 1 \mathrm{~min}$ soaking time and $10 \mathrm{~min}$ microwave exposure time

\begin{tabular}{ccc}
\hline $\mathrm{ZnSO}_{4}$ concentration & \multicolumn{2}{c}{ Percent reduction (\%) } \\
\cline { 2 - 3 }$(\mathrm{mM})$ & S. aureus & E. coli \\
\hline 0 & $22 \pm 2$ & $13 \pm 3$ \\
100 & $76 \pm 2$ & $37 \pm 2$ \\
250 & $92 \pm 2$ & $57 \pm 4$ \\
350 & $90 \pm 2$ & $49 \pm 3$ \\
\hline
\end{tabular}

Table 2

Antimicrobial activity of samples prepared using different concentrations of $\mathrm{NaOH}$ under the following conditions: 350 $\mathrm{mM} \mathrm{ZnSO}_{4}, 1$ min soaking time and $10 \mathrm{~min}$ microwave exposure time

\begin{tabular}{ccc}
\hline $\begin{array}{c}\mathrm{NaOH} \text { concentration } \\
(\mathrm{mM})\end{array}$ & \multicolumn{2}{c}{ Percent reduction $(\%)$} \\
\cline { 2 - 3 } & S. aureus & E. coli \\
\hline 0 & $32 \pm 6$ & $17 \pm 2$ \\
200 & $73 \pm 4$ & $31 \pm 2$ \\
500 & $88 \pm 4$ & $38 \pm 2$ \\
700 & $89 \pm 2$ & $43 \pm 3$ \\
\hline
\end{tabular}

\section{Microwave treatment}

Figure 6 presents scanning electron micrographs of samples in different stages of microwave treatment, illustrating how $\mathrm{Zn}(\mathrm{OH})_{2}$ is changed to $\mathrm{ZnO}$. $\mathrm{Zn}(\mathrm{OH})_{2}$ and $\mathrm{ZnO}$ have different microstructures. The structures of $\mathrm{Zn}(\mathrm{OH})_{2}$ are rod-like (Fig. 6a), excessively elongated in one direction. This rod-like structure of $\mathrm{Zn}(\mathrm{OH})_{2}$ is attributed to the large probability that the other $\mathrm{Zn}(\mathrm{OH})_{2}$ particles orient along the $\mathrm{Zn}$ and $\mathrm{O}$ atoms due to electrostatic considerations (Fig. 7). Meanwhile, the structures of $\mathrm{ZnO}$ are particle-like
(Fig. 6b, 6c), which have no excessive elongation in any of the crystallographic directions.

Prior to the microwave treatment, the samples showed antimicrobial activities against $S$. aureus and $E$. coli by reducing the respective bacterial populations by $38 \pm 5 \%$ and $23 \pm 2 \%$ after one hour of contact (Table 3). This is due to $\mathrm{Zn}(\mathrm{OH})_{2}$ deposited on the substrates. The transformation of $\mathrm{Zn}(\mathrm{OH})_{2}$ into $\mathrm{ZnO}$ by the microwave treatment significantly enhanced the antimicrobial properties of the paper. The populations of $S$. aureus and E. coli decreased by as much as $86 \pm$ $3 \%$ and $42 \pm 2 \%$, respectively. 

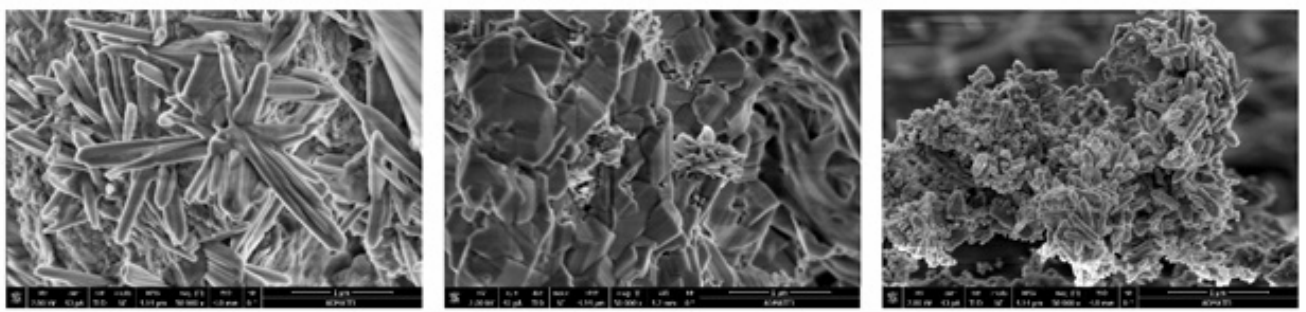

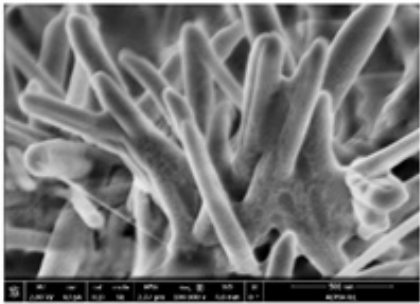

(a) 0 min

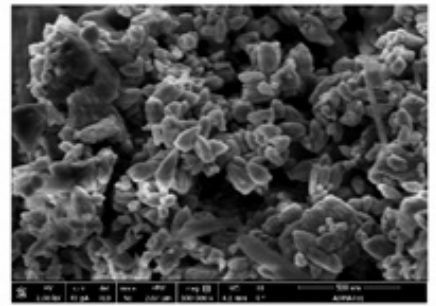

(b) $8 \mathrm{~min}$

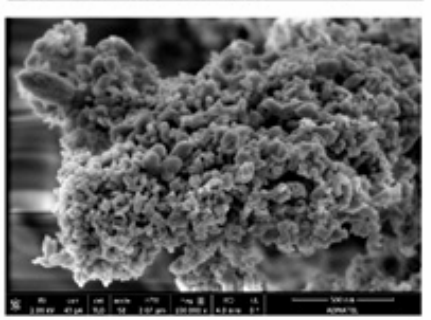

(c) $10 \mathrm{~min}$

Figure 6: Scanning electron micrographs of samples at (a) $0 \mathrm{~min}$, (b) $8 \mathrm{~min}$ and (c) 10 min microwave exposure times, at magnifications of 50,000x (top) and 100,000x (bottom); preparation conditions: $350 \mathrm{mM}$ $\mathrm{ZnSO}_{4}, 700 \mathrm{mM} \mathrm{NaOH}$ and 1 min soaking time

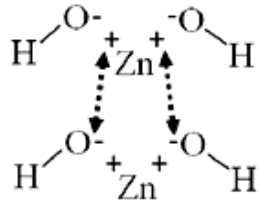

a

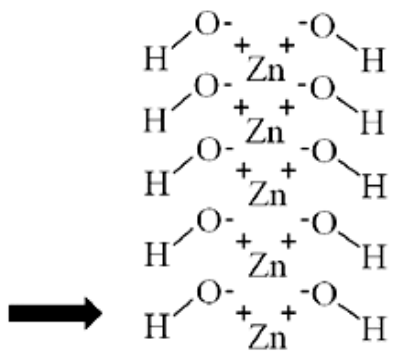

b

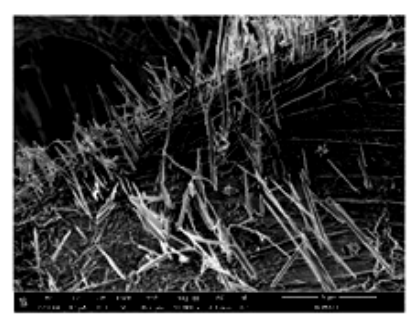

c

Figure 7: Probable mode of interaction of (a) hydroxide and zinc ions to form (b) $\mathrm{Zn}(\mathrm{OH})_{2}$ rods, as shown in (c) scanning electron micrograph of $\mathrm{Zn}(\mathrm{OH})_{2}$ on paper at 10,000x magnification

Table 3

Antimicrobial activity of samples using different microwave exposure times under the following conditions: $350 \mathrm{mM} \mathrm{ZnSO}_{4}, 700 \mathrm{mM} \mathrm{NaOH}$, and 1 min soaking time

\begin{tabular}{ccc}
\hline $\begin{array}{c}\text { Microwave exposure time } \\
\text { (min) }\end{array}$ & \multicolumn{2}{c}{ Percent reduction (\%) } \\
\cline { 2 - 3 } & S. aureus & E. coli \\
\hline 0 & $38 \pm 5$ & $23 \pm 2$ \\
6 & $80 \pm 3$ & $39 \pm 5$ \\
8 & $86 \pm 3$ & $37 \pm 3$ \\
10 & $84 \pm 4$ & $42 \pm 2$ \\
\hline
\end{tabular}

\section{Antimicrobial property}

In general, the $\mathrm{ZnO}$-deposited papers exhibited greater antimicrobial activity towards $S$. aureus than E. coli. Higher antimicrobial activities of some materials against $S$. aureus, compared to $E$. coli, have also been observed and reported earlier. ${ }^{19-22}$ These antimicrobial activities may have arisen from zinc ions released slowly from the zinc oxide and absorbed by the cell. ${ }^{23}$ Within the intracellular compartment of the cell, metal ions may interact directly with functional groups of proteins and nucleic acids, inhibiting the growth of the microorganism, by interfering with normal processes and changing the structure of the cell. E. coli is a gram-negative bacterium. Its cell wall is composed of a thin layer of peptidoglycans, surrounded by an outer membrane containing lipoproteins, phospholipids, 
and lipid polysaccharides (LPS). This barrier allows the entry of only certain macromolecules. $S$. aureus, on the other hand, is a gram-positive bacterium. Although it is surrounded by layers of peptidoglycans, which are many times thicker than that found in gram-negative bacteria, it lacks an outer membrane. Furthermore, gram-positive bacteria have an abundance of pores, allowing the penetration of foreign materials.

\section{CONCLUSION}

We have successfully prepared antibacterial paper using microwave-assisted two-pot in-situ deposition of zinc oxide on filter paper. In this technique, $\mathrm{ZnSO}_{4}$ was used as precursor, while $\mathrm{NaOH}$ served as precipitating agent. Sequential dipping in $\mathrm{ZnSO}_{4}$ and $\mathrm{NaOH}$ allowed the formation and deposition of $\mathrm{Zn}(\mathrm{OH})_{2}$ in the substrates. Afterwards, the samples were subjected to microwave treatment to facilitate the transformation of $\mathrm{Zn}(\mathrm{OH})_{2}$ to $\mathrm{ZnO}$. Of the different preparation parameters, only the variations in $\mathrm{NaOH}$ concentration resulted in distinguishable changes in the masses of the samples and, by inference, the amount of deposited $\mathrm{ZnO}$ particles. Compared to the one-pot technique, this two-pot technique localizes the insitu deposition of zinc oxide on or near the surface of the paper, instead of in the entire solution, thus avoiding wastage of raw materials and minimizing formation of by-products. The two-pot technique may be employed in the deposition of other metal oxides on paper or on other cellulose-based materials.

The zinc oxide-deposited papers were found to be effective against $S$. aureus and $E$. coli. The samples prepared using higher concentrations of $\mathrm{ZnSO}_{4}$ and $\mathrm{NaOH}$ showed better antimicrobial properties. The $\mathrm{ZnO}$-deposited papers were able to reduce bacterial populations by as much as 92 $\pm 2 \%$ for $S$. aureus and $57 \pm 4 \%$ for $E$. coli after one hour of contact. In the future, the zinc oxidedeposited papers can be tested against other species of bacteria and fungi. In general, antimicrobial paper can be tailored to become surface cover, patches, linings, curtains, mats and many others, which can potentially minimize the spread of pathogens.

ACKNOWLEDGEMENT: This research is funded by Philippine Council for Industry, Energy, and Emerging Technology Research and Development (PCIEERD) Grant-In-Aid Program with project number 04013 .

\section{REFERENCES}

1 C. L. Morelli, M. Mahrous, M. N. Belgacem, M. C. Branciforti, R. E. S. Bretas et al., Ind. Crop. Prod., 70, 134

(2015),

https://doi.org/10.1016/j.indcrop.2015.03.036

2 B. Sumiga, B. Sumiga, D. Ravnjak and B. B.

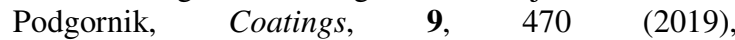
https://doi.org/10.3390/coatings 9080470

3 S. Zakaria, C. H. Chia, W. H. W. Ahmad, H. Kaco, S. W. Chook et al., Sains Malays., 44, 905 (2015), http://www.ukm.my/jsm/pdf_files/SM-PDF-44-62015/18\%20Sarani\%20Zakaria.pdf

4 L. F. Zemljic, J. V. Valh and T. Kreze, Cellulose Chem. Technol., 51, $75 \quad$ (2017), https://www.cellulosechemtechnol.ro/pdf/CCT12(2017)/p.75-81.pdf

5 P. Nechita, E. Bobu, G. Parfene, R. M. Dinica and T. Balan, Cellulose Chem. Technol., 49, 625 (2015), https://www.cellulosechemtechnol.ro/pdf/CCT78(2015)/p.625-632.pdf

6 A. P. Cano, A. V. Gillado, A. D. Montecillo and M. U. Herrera, Mater. Chem. Phys., 207, 147 (2018), https://doi.org/10.1016/j.matchemphys.2017.12.049

7 Y. H. Ngo, D. Li, G. P. Simon and G. Garnier, $A d v$. Colloid Interface Sci., 163, 23 (2011), https://doi.org/10.1016/j.cis.2011.01.004

8 S. Kamel, Carbohyd. Polym., 90, 1538 (2012), https://doi.org/10.1016/j.carbpol.2012.07.027

9 S. V. Costa, A. S. Goncalves, M. A. Zaguete, T. Mazon and A. F. Nogueira, Chem. Commun., 49, 8096 (2013), http://doi.org/10.1039/c3cc43152e

${ }_{10}$ Y. Chen, H. Chung, J. Nychka and L. Liu, RSC Adv., $\quad$ 5, $\quad 91001 \quad$ (2015), http://doi.org/10.1039/C5RA15970A

11 X. Li, Y. H. Wang, C. Zhao and X. Liu, ACS Appl. Mater. Interfaces, 6, $22004 \quad$ (2014), http://doi.org/10.1021/am504903b

12 M. Y. Soomro, I. Hussain, N. Bano, J. Lu, L. Hultman et al., J. Nanotechnol., 2012, 1 (2012), http://doi.org/10.1155/2012/251863

13 H. Liu, Y. Zhang, H. Yang, W. Xiao and L. Sun, J. Chem., 2016, 1 (2016), http://dx.doi.org/10.1155/2016/2862567

14 S. Baruah, M. Jaisai, R. Imani, M. M. Nazhad and J. Dutta, Sci. Technol. Adv. Mater., 11, 055002 (2010), http://doi.org/10.1088/1468-6996/11/5/055002

15 K. Ghule, A. V. Ghule, B. J. Chen and Y. C. Ling, Green Chem., $\quad 8, \quad 1034 \quad$ (2006), http://doi.org/10.1039/b605623g

16 M. Sandberg, D. Tordera, H. Granberg, A. Sawatdee, D. Dedic et al., Flex. Print. Electron., 4, $044003 \quad$ (2016), http://doi.org/10.1088/20588585/1/4/044003

17 A. Pimentel, A. Samouco, D. Nunes, A. Araujo, R. Martins et al., Materials, 10, 1308 (2017), http://doi.org/10.3390/ma10111308

18 S. Tiwari, M. Vinchurkar, V. R. Rao and G. Garnier, Sci. Rep., 7, $43905 \quad$ (2017), http://doi.org/10.1038/srep43905 
19 A. R. Ramos, A. K. G. Tapia, C. M. N. Piñol, N. B. Lantican, M. L. F. del Mundo et al., Mater. Chem. Phys., 238, 121972 (2019), https://doi.org/10.1016/j.matchemphys.2019.121972

20 A. R. Ramos, A. K. G. Tapia, C. M. N. Piñol, N. B. Lantican, M. L. F. del Mundo et al., J. Sci. Adv. Mater. Devices, 4 , 66 (2019), https://doi.org/10.1016/j.jsamd.2018.12.009

21 A. Y. Booshehri, R. Wang and R. Xu, Chem. Eng. J., 262, $999 \quad$ (2015), https://doi.org/10.1016/j.cej.2014.09.096
22 M. Premanathan, K. Karthikeyan, K. Jeyasubramanian, and G. Manivannan, Nanomed. Nanotechnol. Biol. Med., 7, 184 (2011), https://doi.org/10.1016/j.nano.2010.10.001

23 W. Song, J. Zhang, J. Guo, J. Zhang, F. Ding et al., Toxicol. $\quad$ Lett., $\quad$ 199, $389 \quad$ (2010), https://doi.org/10.1016/j.toxlet.2010.10.003 